In general, the literature on graduate student unionization reveals three trends: graduate students with employment contracts, generally considered as employees and able to join unions (e.g., Finland, Sweden, etc.); graduate students considered as students and represented only by general interest unions/associations (e.g., Australia and the United Kingdom); and graduate students considered as both students and employees and able to participate in unions (e.g., Canada and United States). What is unique to the United States is perhaps that, no matter how contentious, the unionization effort is likely to continue vigorously, fueled by sentiment against the growing corporatization of higher education institutions, which some strongly associate with the "exploitation" of graduate students and adjunct faculty. This is, conceivably, further exacerbated by the ever-increasing tuition and fees that leave graduates with a pile of debt, and the overall divisive political climate.

DOI: http://dx.doi.org/ıo.6oI7/ihe.20I8.95.10695

\section{The Future of American Undergraduate Education}

\section{Michael S. McPherson and Francesca B. Purcell}

Michael S. McPherson is president emeritus, Spencer Foundation, and cochaired the American Academy of Arts and Sciences' Commission on the Future of Undergraduate Education. E-mail: mmcpherson@spencer. org. Francesca B. Purcell is program director, Education and the Development of Knowledge program at the American Academy of Arts and Sciences, US. E-mail: fpurcell@amacad.org.

To read The Future of Undergraduate Education, The Future of America, and other publications issued by the Commission on the Future of Undergraduate Education, please visit www. amacad.org/cfue.

$\mathrm{P}$ rogress toward universal basic and secondary education in most countries has been slow and difficult, but the global trend over time is toward greater opportunity for more students from different backgrounds and regions. Building upon its history of educational expansion for young learners, the United States is now approaching universal access to postsecondary education with almost 90 percent of high school graduates enrolling in a two- or four-year college or university during young adulthood. Unfortunately, serious limitations must be addressed for more students to gain the economic and personal benefits that come along with a college education and for the country to continue as a democratic nation of economic opportunity. To ensure that students receive the education they need, we must focus on completion and affordability while more strongly emphasizing quality.

\section{Improving Completion and Affordability}

Like many higher education institutions worldwide, American colleges and universities struggle with completion and affordability. In the United States, too few students graduate, with only about 55 percent of students completing a college credential. More students are borrowing more money to pay for college, with over 60 percent taking out loans; and those who do not graduate are the most likely to have trouble paying back their loans, further limiting their economic opportunity. These obstacles are particularly acute for underrepresented minorities and students from low-income families, meaning that the country is missing out on large reservoirs of human potential. Many institutions, policy groups, and researchers now focus on completion and affordability and many promising practices show solid results. For example, Florida State University increased its completion rates from $\sigma_{3}$ to 79 percent over a period of years using data to identify barriers and implementing support structures to help students. The Australian and English income-based loan programs are exemplars in helping to reduce default rates and the United States should draw upon these models.

In addition to completion and affordability, greater attention needs to be paid to the purposes of the learning that takes place during college and how we may realistically deliver on this promise of future prosperity.

\section{Taking College Teaching More Seriously}

Debates over the value of vocational versus liberal arts education have a long history in the United States, but this perceived division is a false choice; college graduates need to master a range of academic, practical, and civic skills. Students in every field need to acquire a blend of abilities associated with the liberal arts such as communication, critical thinking, and teamwork in addition to technical and practical skills. These students will stand the best chance of performing effectively at work, participating in their communities, and learning over their lifetimes.

Over the past 40 years, a growing body of research has deepened our understanding of how people learn and, in turn, has brought insights into how teachers can best teach. This research offers a range of evidence-based teaching practices linked with a host of positive outcomes including increased student learning, reductions in achievement gaps, and increased persistence. Yet the use of evidence-based teaching techniques throughout the country's 4,700 colleges and uni- 
versities is not the norm, even though the primary determinant of a quality education is the teaching and learning relationship between faculty and students.

Across many institutions, more attention is paid to faculty research than to faculty teaching. Relatively little focus on measuring and observing teaching performance takes place, except for student questionnaires, which are generally a weak indicator of performance. The things that we know do work are not widely used. For example, the K-I2 education sector shows that conscientious observation of classrooms by trained individuals with organized ways of providing feedback can be very effective in improving teaching performance. However, this practice is far from the norm throughout American college classrooms.

\section{These obstacles are particularly acute for underrepresented minorities and students from low-income families, meaning that the country is missing out on large reservoirs of human potential.}

The reality is that the main occupation of the majority of college faculty is teaching undergraduates, yet faculty often get very little initial training, ongoing support, or recognition for this central work. Further, the growing number of "contingent" faculty-an international trendallows institutions to save money by relying more heavily on short-term, part-time instructors who are paid less, have few benefits and negligible job security, and often lack a voice in governance. Even more concerning, they often have scant time and opportunity to engage with students. And yet, contingent faculty now account for at least half of all instructional faculty at the country's public research universities and more than 80 percent at our two-year public community colleges.

In short, college teaching needs to be taken far more seriously. Even if the United States graduates more students and reduces debt levels, this will be an empty and expensive victory if students are not equipped with the knowledge, skills, and attitudes required to navigate their lives well.

\section{Making Progress}

The transformation of a teaching workforce rooted in disciplinary expertise to include pedagogical expertise will not be easy. Colleges and universities first need to signal unambiguously that they care about teaching. More institu- tions should give more weight to effective teaching practices when faculty are being evaluated for promotion or contract renewal. This should be accompanied by making mentoring and other structured resources available to faculty. Those faculty - and there are many-who devote time and energy to improving their teaching need to be singled out and rewarded.

Institutions must be willing to find the resources and determination to improve the working conditions of faculty who are in part-time positions and, where they can, aim to make these positions full-time with longer-term contracts. We suspect that for many of these faculty, respectful treatment and a voice in governance count at least as much as extra dollars in their paycheck. Without these changes, it will be hard to make progress in any substantial way.

We also must reconsider the whole concept of what it means to be a teaching professional. Master's and doctoral programs that graduate students who go on to teach at the postsecondary level should include meaningful teacher training opportunities. Currently, the PhD is almost exclusively a research degree and not a teaching degree, although plenty of doctoral students go on to teach full-time.

Although American higher education faces huge challenges, there are also real reasons for optimism. For all of the doubts raised about the benefits of a college education, it delivers on its promises of greater individual and social prosperity; more institutions are improving in their efforts to graduate students; and technological opportunities enacted carefully are further increasing student success. Progress is not guaranteed, and good things will happen only with sustained effort, but if we can sustain focus on the work, combining patience with urgency, we can, through undergraduate education, make great advances as individuals and as a nation.

DOI: http://dx.doi.org/10.6oI7/ihe.2018.95.10696 